\title{
STUDI AL-QUR'AN SEBAGAI PEMICU-PEMACU PERADABAN: TELAAH SOSIO-HISTORIS
}

\author{
Muhammad Taufik \\ Universitas Islam Negeri (UIN) Mataram \\ taufik.bm25@yahoo.com
}

\begin{abstract}
$V$ arious studies have been expressed about the progress of Islamic civilization which is strongly influenced by contact with outside traditions, both Greek, Persian, Indian, and so forth. But the important thing that also needs to be underlined is that Islam itself has the values and teachings of the Qur'an which is the main driver of the birth of Islamic civilization. The Qur'an has a very vital and respected position in Muslim communities throughout the world. Aside from being a source of law, moral guidance, guidance of worship and doctrine of the faith, the Qur'an is also a bistorical and universal source of civilization. This paper will further explore how the embodiment of Islam as a civilization and the historicity of the Qur'an as a trigger for civilization.
\end{abstract}

Keywords: Quranic studies, Islamic civilization, socio-historical perspective.

\begin{abstract}
Abstrak
Ragam kajian telah diutarakan seputar kemajuan peradaban Islam yang sangat dipengaruhi oleh pesentuhan dengan tradisi luar, baik Yunani, Persia, India, dan lain sebagainya. Namun hal penting yang juga patut digarisbawahi tebal-tebal adalah bahwa di dalam Islam sendiri telah memiliki nilai dan ajaran Al-Qur'an yang menjadi pendorong utama lahirnya peradaban Islam. Al-Qur'an memiliki posisi yang amat vital dan terhormat dalam masyarakat Muslim di seluruh dunia. Di samping sebagai sumber hukum, pedoman moral, bimbingan ibadah dan doktrin keimanan, Al-Qur'an juga merupakan sumber peradaban yang bersifat historis dan universal. Tulisan ini lebih lanjut hendak menlusuri bagaimana perwujudan Islam sebagai sebuah peradaban dan historisitas al-Qur'an sebagai pemicu dan pemacu peradaban.
\end{abstract}

Kata Kunci: Studi Al-Qur'an, peradaban Islam, perspektif sosio-historis.

\section{PENDAHULUAN}

Al-Qur'an memiliki posisi yang amat vital dan terhormat dalam masyarakat Muslim di seluruh dunia. Di samping sebagai sumber hukum, pedoman moral, bimbingan ibadah dan doktrin keimanan, Al-Qur'an juga merupakan sumber peradaban yang bersifat historis dan universal. Dalam makna lain, fungsi Al-Qur'an sebagai budan ini merupakan pusaka pegangan dalam berperilaku dalam

mengemban amanah kekhalifahan. ${ }^{1}$ Fungsifungsi lainnya, betapa pun pentingnya, tidak boleh melupakan fungsi primer ini.

Posisinya yang demikian penting inilah yang membuat Al-Qur'an menjadi pusat perhatian yang demikian besar dalam khazanah keilmuan Islam, sejak masa Rasulullah Saw hingga kini di era kontemporer. Perwujudan posisi penting tersebut tampak dari proses

${ }^{1}$ M. Luthfi, 'Membumikan Al-Qur'an: Peluang Dan Tantangan', Al Qalam 20, no. 98 (2003): 21-40. 
pencatatan Al-Qur'an ketika pertama kali disampaikan Nabi Muhammad kepada para sahabatnya, pembukuannya menjadi mushaf, penafsiran, perumusannya menjadi sebuah disiplin keilmuan mandiri. Selain itu, menjamurnya karya-karya kesarjanaan yang berupaya mengungkap kandungan maknanya, juga menjadi bentuk manifestasi arti penting Al-Qur'an. Belum lagi jika melihat karya-karya kesarjanaan seputar 'ilmu bantu' dalam memahami Al-Qur'an yang di kemudian hari membentuk keilmuan baru yang dikenal dengan istilah 'ulum al-Qur'an. ${ }^{2}$

Nabi yang mulia Muhammad Saw. pernah menegaskan bahwa "Man ta'allam AlQur'an wa 'allamubu kāna ma'iya fi al-Jannab". Dari hadis tersebut bisa dipahami bahwa betapa tinggi dan mulianya posisi orang yang belajar dan mengajarkan Al-Qur'an. ${ }^{3}$ Tentu saja termasuk di dalamnya adalah pihak yang merancang-melaksanakan program yang memfasilitasi proses belajar dan mengajar AlQur'an itu.

Secara historis dalam dunia Islam, yang utama dan paling pertama, yang dijadikan sebagai basis adalah memang studi Al-Qur'an. Mulai dari membaca, menghafal, memahamimencintai hingga mewujudkan kandungannya itu dalam praktik kehidupan nyata sehari-hari. Dalam dunia Islam hingga hari ini dan seterusnya, Al-Qur'an akan tetap dan terus menjadi bahan ajar utamanya, dan dalam versivariasi yang sangat beragam, karena memang Al-Qur'an adalah sebuah dokumen-kitab yang

2 Ah Fawaid, 'Dinamika Kajian Al-Qur'an Di Barat Dan Dampaknya Pada Kajian Al-Qur'an Kontemporer', Nuansa 10, no. 2 (2013): 229-58, https://doi.org/10.19105/nuansa.v10i2.170.

${ }^{3}$ Buah/hasil belajar dan mengajarkan Al-Qur'an dalam hadis tersebut bisa difahami dalam berbagai level. Mulai secara literal memahami cara baca hurufkalimatnya, memahami bahasanya, memahami hikmahnya, nilainya serta memahami kandungannya, hinggga memahami bagaimana mencintai Al-Qur'an untuk lebih lanjutnya bisa menjadi pedoman-penuntun moral dan kelakuan dalam berkehidupan secara praksis. tidak berbatas dalam hal kedalaman-keluasan muatannya. Dimensi historis ini tidak bisa diabaikan. Tujuannya agar manusia, khususnya umat Islam, tidak terjebak pada konklusikonklusi parsial dan apologi-apologi. Al-Qur'an memiliki karakteristik yang sangat khas dan berbeda dibandingkan dengan dokumen lain yang merupakan hasil kreasi umat manusia.

Ragam kajian telah diutarakan seputar kemajuan peradaban Islam yang sangat dipengaruhi oleh pesentuhan dengan tradisi luar, baik Yunani, Persia, India, dan lain sebagainya. Namun hal penting yang juga patut digarisbawahi tebal-tebal adalah bahwa di dalam Islam sendiri telah memiliki nilai dan ajaran Al-Qur'an yang menjadi pendorong utama lahirnya peradaban Islam. Sebagaimana diungkap Seyyed Hossein Nasr bahwa term Islam yang melekat dalam ragam frasa seperti "filsafat Islam", bersifat Islam bukan hanya karena ia dibudidayakan di dunia Islam dan dilakukan oleh kaum Muslim, melainkan karena filsafat Islam menjabarkan prinsipprinsip dan menimba inspirasi dari sumbersumber wahyu Islam serta menangani banyak permasalahan dengan sumber-seumber tersebut kendatipun ada klaim-klaim yang berlawanan dari para penentangnya. ${ }^{4}$

Tulisan ini lebih lanjut akan melihat bagaimana perwujudan Islam sebagai sebuah peradaban dan historisitas al-Qur'an sebagai pemicu dan pemacu peradaban.

\section{ISLAM SEBAGAI PERADABAN}

Secara normatif, Islam adalah agama yang berasal dari Allah, sedangkan peradaban merupakan produk budi manusia melalui daya cipta, rasa, dan karsanya. Relasi antara Islam dan peradaban ini kemudian mejadi menarik karena kehadiran Islam dan perkembangannya

${ }^{4}$ Seyyed Hossein Nasr, 'Al-Qur'an Dan Hadis Sebagai Sumber Dan Inspirasi Filsafat Islam', in Ensiklopedi Filsafat Islam, ed. Sayyed Hossein Nasr and Oliver Leaman (Bandung: Mizan, 2003), 36. 
di banyak kawasan kemudian melahirkan sebuah peradaban yang disebut dengan peradaban Islam. ${ }^{5}$

Peradaban Islam berasal dari din (agama) yang bersumber dari wahyu Allah. Sehingga peradaban Islam biasa dikenal juga dengan istilah tamaddun atau madaniyyah. ${ }^{6}$ Bahkan oleh banyak kalangan, Islam diakui sebagai sebuah agama sekaligus peradaban (Islam is both a religion and a civilization). Karena di samping mengandung nilai dan ajaran normatif, Islam juga merupakan kreator dan spritit yang hidup bagi sebuah peradaban besar dunia yang eksistensinya terbentang luas lebih dari 14 abad. $^{7}$

Pengakuan akan Islam sebagai sebuah agama sekaligus peradaban, misalnya oleh seorang orientalis kontemporer Bernard Lewis yang mengatakan, "Islam - the offspring of Arabia and the Arabian Prophet - was not only a system of belief and cult. It was also a system of state, society, law, thought and art, a civilization with religion as its unifying eventually dominating factor." 8 Artinya, antara Islam dan peradaban tidaklah dapat dipisahkan karena konsep dan misi peradaban merupakan sesuatu yang inheren sejak awal kehadiran Islam.

Kehadiran Islam dengan penanaman nilai-nilai perdaban yang bersumber dari agama (din) menjadikan negeri Arab tampil sebagai negeri ber-tamaddun (madaniyyah). Meski harus diakui bahwa ada semacam pengaruh dari berbagai peradaban lain seperti Yunani, Persia, India, Romawi, dan lain sebagainya, namun

${ }^{5}$ J. Suyuthi Pulungan, Sejarah Peradaban Islam (Palembang: Grafindo Telindo Press, 2009), 18.

6 Qosim Nursheha Dzulhadi, 'Islam Sebagai Agama Dan Peradaban', Tsaqafah: Jurnal Peradaban Islam 11, no. 1 (2015): 151-68, https://doi.org/http://dx.doi.org/10.21111/tsaqafah.v $11 \mathrm{i} 1.258$

${ }^{7}$ Seyyed Hossein Nasr and Huston Smith, Islam: Religion, History and Civilization (Lahore: Suhail Academy, 2005), xi.

${ }^{8}$ Bernard Lewis, The Arab in Hostory (New York: Harper \& Row Publisher, 1967), 113. nilai-nilai perdaban asing tersebut telah melalui filterisasi. Beberapa hal penting yang menjadi fondasi dalam proses pembangunan peradaban Islam adalah sebagai berikut:

Pertama, transmisi pandangan hidup dan keyakinan (al-naqlah al-tasammuriyyah ali'tiqädiyyah). Aspek ini merupakan sesuatu yang paling penting dalam pendasaran perubahan dalam bentuk apapun di suatu masyarakat. Karena di dalamnya mengandung perubahan keyakinan menuju tauhid; dari penyembahan kepada manusia menjadi penyembahan hanya kepada Tuhan; dari pengabdian kepada berhala menjadi pengabdian kepada Allah. Kedua, transmisi keilmuan (al-naqlah al-márifizyah). Dalam term lain disebut dengan tahawnul ma'rifi (perubahan ilmiah). Dalam konteks Islam, perubahan ini telah dimulai sejak turunya wahyu pertama: Iqra! Berangkat dari ayat ini, kemudian seruan al-Qur'an terus memancar dari aktivitas membaca dan berpikir, menggunakan nalar (ta'aqqu), kontemplasi (tadabbur), dan seterusnya, memancar dalam sinaran Kitabullah. Ketiga, transmisi metodologis. Transmisi ini diyakini secara umum merupakan bagian penting yang tak dapat dilepaskan dari dua transmisi sebelumnya dan berperang vital dalam alur pemikiran manusia serta peradaban secara umum. ${ }^{9}$

Terkait dengan karakteristik peradaban Islam di atas, Ashimi mengemukakan 5 karakteristik khas yang terdapat dalam peradaban Islam, yakni: based on the Tawhid, universality, moderate rationalism, tolerance, integrated and balanced civilization. Lebih lanjut, ia juga mencatat bahwa faktor-faktor penting yang melatari kemunculan peradaban Islam dengan karakteristik tersebut adalah: spritual power, ability to transform the ideals of the Qur'an to daily

${ }^{9}$ Imad al-Din Khalil, Madkhal Ila Hadharah AlIslamiyyah (Lebanon: al-Markaz al-Tsaqafi al-'Arabi, 2005), 15-18. 
conduct, intellectual freedom, opennes, dan the spirit of seeking knowledge. ${ }^{10}$

\section{HISTORISITAS AL-QUR'AN SEBAGAI PEMICU-PEMACU PERADABAN}

Al-Qur'an adalah kalämullah, yang secara substansial filosofis dan teo-spiritual, diturunkan (nu₹ul Al-Qur'an) secara sangat cepat dan rahasia (wahy) yang secara hakiki tanpa suara dan tanpa huruf. Al-Qur'an merupakan kalàm Allah yang diwahyukan kepada Nabi Saw. sebagai penerima wahyu verbal Tuhan terakhir. ${ }^{11}$ Hanya saja keyakinan yang teramat penting dalam struktur keislaman ini memerlukan penjelasan yang lebih memadai dan bertanggung jawab.

Dalam perspektif psikologis, dapat dijelaskan bahwa bagi Al-Qur'an sendiri dan konsekuensinya juga bagi kaum Muslim, AlQur'an adalah Kalām Allah, dan Muhammad Saw. benar-benar meyakini bahwa dia adalah penerima pesan dari Tuhan, Zat yang sama sekali lain melalui suatu saluran 'mendiktekan' Al-Qur'an dengan otoritas mutlak. ${ }^{12}$

Dari kutipan tersebut tampak bahwa sementara sumber dan asal dari proses kreatif ini terletak di luar capaian biasa agensi (keperantaraan) manusia, namun proses ini timbul dalam suatu pengertian yang pasti, sebagai suatu bagian integral dari pikiran perantara. Jika keseluruhan proses timbul dalam pikirannya, maka perkataannya-dalam suatu pengertian yang biasa-merupakan katakatanya, sepanjang menyangkut pertimbangan proses psikologis ini, tetapi perkataan itu juga

10 Tijani Ahmad Ashimi, 'Islamic Civilization: Factors Behind Its Glory and Decline', International Journal of Bussiness, Economics and Law 9, no. 5 (2016): 180-84.

11 Fazlur Rahman, Wabyu Ilabi Dan Nabi (Bandung: Mizan, 1989), 44.

12 Fazlur Rahman, Islam (Chicago: The University of Chicago Press, 1979), 30-39. merupakan kaläm yang diwahyukan sepanjang sumbernya terletak di luar capaiannya. ${ }^{13}$

Menjawab tuntutan kebutuhan membangun karaktertistik ilahiah murni dari wahyu Al-Qur'an dan keunikannya itu, perlu dilihat potensialitas kenabian dalam pandangan sekelompok filsuf Muslim yang tergabung dalam Ikhwān al-Ṣafā. Secara garis besar, di antara kualitas-kualitas kenabian, yang paling penting dan utama adalah visi atau penglihatan yang benar (al-ruiyah al-șädiqah).

Sementara itu, dari 12 (dua belas) kualitas bawaan yang sejak lahir dimiliki seorang Nabi, dua di antaranya harus mendapat perhatian khusus: pemahaman yang unggul dan kecepatan imajinasi. Ia harus memiliki pemahaman yang unggul dan kecepatan imajinasi sekitar apapun yang dikatakan kepadanya dan apa yang dikatakannya sendiri. Kemudian, dari sepuluh kualitas yang menjadi tambahannya, dua kualitas patut dicatat: pertama, kemampuan Nabi dalam mempersepsi realitas-realitas spiritual tanpa bentuk-bentuk materialnya; dan kedua, kemampuan Nabi dalam memvisualisasi yang ada yang bersifat spiritual (spiritual being), dengan atau tanpa bantuan badan-badan tubuh. $^{14}$

Dalam kaitan ini, "seorang Nabi berbeda dengan dan dari orang lain dikarenakan kekuatan fakultas imajinasinya", ${ }^{15}$ dengan argumentasi bahwa semangat dasar (the basic elan) Al-Qur'an adalah moral, dari mana mengalir penekanannya yang tegas terhadap monoteisme maupun keadilan sosial. Adapun dalam hal kekuatan persepsi kognitif, manusia memiliki perbedaan tegas antara satu dengan lainnya hingga taraf yang tidak terbatas.

13 Rahman, Wabyu Ilabi Dan Nabi, 40-41.

${ }^{14}$ Sebagaimana dikutip oleh Ismail K. Poonwala, 'Al-Qur'ān Dalam Rasāil Ikhwān Al-Ṣafā', Ulumul Qurān 9, no. 2 (1991): 39.

15 Fazlur Rahman, Prophecy in Islam: Philosophy And Ortodoxy (London: George Allen \& Unwin LTD, 1938), 36. 
Lebih jauh, perspesi moral dan keagamaan juga sangat berbeda dari sematamata persepsi intelektual, karena suatu kualitas hakiki dari yang pertama adalah bahwa bersama-sama dengan persepsi, ia membawa suatu rasa 'daya tarik' (sense of gravity) yang istimewa serta menjadikan subjeknya tertransformasikan secara signifikan.

Nah, seorang Nabi adalah seseorang yang keseluruhan karakter dan prilaku aktualnya jauh lebih tinggi dari manusia pada umumnya. Ia merupakan seseorang yang $a b$ initio (dari awalnya) tidak sabar terhadap manusia dan bahkan terhadap sebagian besar ideal-ideal mereka, serta berkehendak menciptakan kembali sejarah. Muhammad Saw. adalah manusia seperti itu, dan dalam kenyataannya satu-satunya manusia seperti itu yang dikenal sejarah. Itulah sebabnya seluruh perilakunya dipandang oleh kaum Muslimin sebagai sunnah atau 'model sempurna'. Dengan demikian Al-Qur'an adalah murni Kalam Ilahi. Kalam Ilahi tersebut mengalir melalui hati Nabi. ${ }^{16}$

Dari pernyataan tersebut bisa dipahami bahwa pejelasan psikologis proses pewahyuan berguna untuk memperkuat keyakinan akan kebenaran Al-Qur'an sebagai firman Tuhan yang sepenuhnya murni Ilahi, bukan untuk membenarkannya. Sebab Al-Qur'an memang benar adanya. ${ }^{17}$ Implikasi dari argumen psikologis ini meskipun telah berusaha memisahkan karakteristik wahyu Al-Qur'an yang ilahiah-unik dari bentuk pengetahuan kognitif kreatif lainnya, masalah krusial muncul dalam kaitannya dengan finalitas kenabian Muhammad, ${ }^{18}$ sebab argumen psikologis

16 Rahman, Islam, 32-33.

${ }^{17}$ Di antaranya seperti yang ditulis oleh Manna Khalīl al-Qattān, Studi Ilmu-Ilmu Al-Qur`ān (Jakarta: Pustaka Litera Antar Nusa, 1996), 48-49.

${ }^{18}$ Seperti ditegaskan dalam Qs. al-Aḥzāb/33:40, Muhammad itu sekali-kali bukanlah bapak dari seorang laki-laki dari antara kamu, tetapi dia adalah Rasūlullāh penutup nabi-nabi. menyiratkan arti bahwa wahyu Tuhan selalu terbuka bagi umat manusia.

Terhadap hal ini bisa dipahami bahwa melalui Islam dan Kitab-nya manusia telah mencapai kedewasaan secara rasional dan moral. Setelah Muhammad, manusia mampu bergerak ke depan dengan petunjuk kolektif; dan petunjuk individual dari hakekat suatu risalah kenabian (setelah Muhammad) tidak dibutuhkan lagi. ${ }^{19}$ Dan, bahwa kedewasaan moral seorang manusia tergantung pada perjuangannya yang terus menerus mencari petunjuk dari kitab-kitab Allah-khususnya AlQur'an-dan bahwa manusia belum menjadi dewasa dengan pengertian ia dapat hidup tanpa petunjuk Allah.

Dalam tradisi hermeneutika, ${ }^{20}$ sebuah petunjuk akan berfungsi dengan mengandaikan beberapa syarat. Pertama, seseorang mesti paham apa yang dikandung oleh petunjuk itu. Misalnya saja, ketika ke Jepang, saya tiba-tiba menjadi buta huruf lantaran dihadapkan dengan beberapa keterangan dan petunjuk jalan dalam huruf kanji dan bahasa Jepang. Demikian pula apa yang dikandung Al-Qur'an. Ketika seseorang tidak mampu membaca dan menangkap pesannya, petunjuk itu tidak berfungsi. Kedua, ibarat petunjuk jalan, kalau seseorang paham tetapi tidak mau menaati atau dihadapkan pada situasi yang menghalangi, maka lagi-lagi petunjuk itu tidak mengantarkan seseorang pada sasaran yang dituju. Ketiga, ibarat resep dokter, kalau seseorang tidak

19 Fazlur Rahman, 'The Qur'ānic Concept of God, the Universe and Man', Islamic Studies 6, no. 1 (1967): 1-19.

${ }^{20}$ Hermeneutic, secara operasional mengandung tiga makna dasar (1) menyatakan, menegaskan, atau juga mengatakan [to express, to assert, to say]; (2) menjelaskan [to explain] yang menekankan aspek diskursif dalam upaya memahami sesuatu; (3) menerjemahkan [to translate]. Gadamer menyebut hermenutik sebagai the art or technique of understanding and interpretation. Lihat Palmer and Richard E., Hermenutics: Interpretation Theory in Schleurmacher, Dilthey, Heidegger, and Gadamer (Evanston: Northwestern University Press, 1969), 12. 
berdisiplin mengikuti petunjuknya agar memakan obat serta menjaga gaya hidup sehat, maka sulit baginya untuk hidup sehat.

Jadi, Al-Qur'an sebagai petunjuk jalan kebenaran dan kebaikan pada implementasinya dikembalikan pada umat Islam sendiri, apakah benar-benar memahami dan mampu melaksanakan ataukah tidak. Bahwa membacanya berpahala, memang itu dibenarkan oleh Rasulullah Saw.

Persoalannya adalah bahwa Al-Qur'an sebagai petunjuk, sebagai pengingat, sebagai pembeda dan seterusnya, akan menjadi sulit atau bahkan tidaklah mungkin bisa berperan secara signifikan sesuai kebutuhan manusia, baik bagi manusia sebagai makhluk individu maupun makhluk komunal, dalam menjalani kehidupannya hari ini dan hari-hari seterusnya, tanpa pemahaman dan kecintaan yang memadai terhadap Al-Qur'an itu.

Dalam sisi inilah, terlihat secara historis betapa pentingnya studi Al-Qur'an itu, dan kedepan, jika umat atau siapa saja berkehendak untuk meraih keberhasilan (tanpa mengalami kenegatifan yang merusak) dalam kehidupan modern-global, maka mau-tidak-mau studi AlQur'an perlu menjadi perhatian secara lebih sunggu-sungguh. Pendek kata, Al-Qur'an bukanlah dokumen yang sarat dengan detaildetail hukum sosial melainkan sebuah Kitab yang mengandung prinsip-prinsip dasar dan moralitas kemanusiaan universal. Penting ditegaskan bahwa semakin banyak hukum absolut yang mengatur pola kehidupan, maka ritme peradaban manusia akan menjadi sangat kaku dan statis. Stagnanasi peradaban ini sangat dimungkinkan apabila doktrin teologis menjadi sangat taken for granted.

Dalam perspektif ini, siapapun, sesungguhnya tidak bisa mengklaim bahwa $\mathrm{Al}$ Qur'an merupakan sumber segalanya, apalagi mengatakan sarat dengan teori-teori sains (science theory). Menurut penelitian para ahli, ayat Al-Qur'an yang berbicara tentang sains hanya sekitar 150 ayat. Menurut pandangan ini, ayatayat tersebut secara paradigmatik tidak cukup untuk dijadikan dasar pemikiran bahwa AlQur'an merupakan kitab yang sarat dengan teori sains, apalagi teknologi modern yang di dalamnya sarat dengan detail-detail. Lebih tepat, jika dikatakan bahwa Al-Qur'an itu mengandung motivasi atau prinsip-prinsip moral yang bersifat normatif untuk melakukan aktivitas sains dan teknologi.

Titik simpul pertautan Al-Qur'an dengan modernisasi terletak pada penggunaan akal pikiran manusia. Baik Al-Qur'an maupun modernisasi sangat mengagungkan akal pemikiran atau dimensi rasionalitas. Perbedaannya, kalau modernisasi mengagungkan akal pikiran secara absolut sedangkan dalam Al-Qur'an akal pikiran itu memperoleh bimbingan wahyu.

Bangunan peradaban yang kokoh selalu ditopang oleh empat pilar utama, yaitu: kekuatan politik yang menjamin kohesi sosial, kekuatan ekonomi yang menjamin kesejahteraan warga, dan pusat-pusat lembaga pendidikan yang berkualitas, serta nilai-nilai luhur keagamaan yang menjadi sumber makna dan tujuan hidup. Keempat pilar ini terlihat jelas dalam sejarah Islam di abad-abad kejayaannya yang lalu.

Di samping kekuatan politik dan ekonomi, dunia Islam memiliki pusat-pusat pendidikan yang berkelas dunia. Penafsiran secara intelektual terhadap ayat-ayat Al-Qur'an berlangsung serempak dengan riset dan penafsiran terhadap ayat-ayat semesta, hukum sejarah dan kajian humaniora yang semuanya merupakan ayat Allah yang saling menafsirkan dan menjelaskan satu terhadap yang lain.

Namun, ketika perhatian pada pengembangan ilmu dan peradaban terabaikan akibat para penguasa disibukkan oleh perebutan warisan politik dan perang antardinasti dan suku berkepanjangan, kurva peradaban Islam menurun. Waktu itu kajian 
Al-Qur'an dipisahkan dari kajian teks kauniyah, tarikhiyahdan nafsiyah yang bersifat induktif dan empiris, lalu wacana keislaman cenderung tekstual-normatif-deduktif.

Padahal janji Allah, bumi ini akan diwariskan pada hamba-hamba-Nya yang saleh. Jadi, untuk melaksanakan misi kekhalifahan manusia guna membangun peradaban di muka bumi tidak bisa dipisahkan dari kesalehan, prestasi iman dan penguasaan ilmu pengetahuan. Saleh pada dimensi esoterik adalah mereka yang imannya teguh, berhati, dan berperilaku mulia, mereka yang senang dan taat beribadah.

Lalu, saleh dalam dimensi eksoterik adalah mereka yang mampu bekerja secara profesional, yang memiliki skill dan kompetensi. Pribadi seperti itulah yang akan dipercaya tidak saja oleh Allah Swt., namun juga oleh manusia, yaitu mereka yang memiliki integritas, skill, dan visioner-orang-orang yang layak menerima sebuah amanat untuk menjadi pemimpin.

Tahapan historis dari konsolidasi sosial-politik, ekonomi dan pendidikan yang pernah dibangun oleh umat Islam di masa lalu sehingga mencapai puncak kejayaan pada zamannya, hal serupa juga terlihat pada eksperimen sejarah di berbagai negara maju di abad modern ini. Negara yang tergolong maju pasca-Perang Dunia II adalah mereka yang berhasil melakukan konsolidasi politik, ekonomi, lalu naik ke tahap pendidikan dan peradaban menjadi agenda utamanya.

Tanpa pendidikan dan pusat riset unggulan yang bertaraf internasional, kekayaan alam yang dimiliki sebuah bangsa tidak sanggup menciptakan berkahkemakmuran (blessing), tapi potensial menjadi sumber bencana (curse). Sebuah nilai tambah (added value) dari kekayaan alam maupun budaya akan diraih ketika sebuah bangsa berhasil mengembangkan ilmu pengetahuan, teknologi, dan peradaban.
Itulah yang pernah dicontohkan Rasulullah Saw. dan para sahabatnya dengan spirit dan panduan Al-Qur'an, sehingga padang pasir Arabia waktu itu yang tidak menarik bagi pengunjung luar tiba-tiba menjadi mata air peradaban yang monumen dan getarannya masih bisa dilihat dan dirasakan sampai hari ini. Sekarang ini kita hidup dalam masyarakat horizontal, "the world is flat". Sebuah momentum dan tantangan untuk menerjemahkan konsep Islam sebagai "rahmat bagi alam" yang menuntut pembuktian empiris-horizontal. Sehebat ajaran agama apa pun yang diyakini secara teologis vertikal, kehebatan dan keunggulannya sulit dipasarkan pada dunia kalau tidak disertai bukti dan prestasi empiris yang terukur dan dapat dirasakan langsung oleh masyarakat pengguna jasa (users).

\section{Kata rahmatan lil'alamin sendiri} mengasumsikan umat Islam harus memiliki mindset kosmopolitanisme, sebagai pengibar panji perdamaian dan peradaban yang disebarkan dengan kasih sayang, ke dalam pergaulan masyarakat global yang sangat plural, baik dari segi bangsa, budaya, maupun agama.

Persoalan mendasarnya adalah, bagaimana agar Al-Qur'an mencapai sasarannya dan nuzul atau turun pada bumi manusia seutuhnya (hati, perasaan, pikiran yang membuahkan amal baik), kemudian berfungsi membawa rahmat bagi kehidupan manusia, tidak saja bagi umat Islam? Syarat pertama: seseorang haruslah menyucikan hatinya (clean heart). Bagi orang yang hatinya tidak bersih, Al-Qur'an sulit. "Lâ Yamassubu illa alMuthabharûn". ${ }^{21}$ Demikianlah bunyi salah satu ayat Al-Qur'an. Hari-hari ini (1 Muharram) dan

\footnotetext{
${ }^{21}$ Tidak boleh-tidak bisa-tidak dapat, menyentuh (dengan hati nurani-perasaan-otak-akal-pikiranperkataan-tulisan-tangan-tindakan dst.) nya (Al-Qur'an pun: fisiknya-maknanya-semangatnya-hikmahnya-nilainilai -hukumnya-kandungannya dst.) kecuali oleh orangorang yang tercerahkan (suci: fisiknya-hatinyaperasaannya-pikirannya-kecerdasannya dst.).
} 
hari-hari seterusnya, dengan memperbanyak ibadah mendekatkan diri kepada Allah, istighfar-memohon ampunan dan selalu berbuat baik, semoga hati kita akan selalu taubah/kembali menjadi bersih sehingga AlQur'an bisa nuzul ke dalam hati kita itu.

Syarat kedua, bila tanpa pikiran kritis, bila tanpa rasa ingin tahu dan selalu ingin berdialog secara cerdas dengan Al-Qur'an, maka Al-Qur'an menjadi seakan bisu, tidak komunikatif pada kita. Sebuah teks akan berbicara dan mengajari kita kalau kita senang bertanya, berdialog dan menangkap kandungannya. Makanya kita-umat ini, mestinya selalu menggunakan akal dan nalar kritis dalam membaca Al-Qur'an beserta makna yang dikandungnya.

Itulah salah satu keunikan dan keunggulan mukjizat Al-Qur'an yang menantang dan sekaligus membimbing penalaran (head) manusia. Syarat ketiga, setelah menggunakan heart/hati dan head/otak-pikiran kritis dengan benar dan optimal, selanjutnya seorang muslim haruslah mengimplementasikan dalam karya dan tindakan nyata dengan hand/anggota raganyawinya, sehingga buah dari keyakinan/kepercayaan/kecintaan dan pemahamannya pada Al-Qur'an bissa dan dapat membuahkan amal saleh, yaitu karya nyata yang benar dan bermanfaat bagi umat manusia.

Semasa Rasulullah Saw., masyarakat Arab padang pasir yang dikenal jahiliah dan senang berperang, dengan bimbingan AlQur'an, hati, pikiran dan perilakunya dipandu oleh Al-Qur'an, sehingga dalam waktu singkat terjadi revolusi peradaban. Dengan gambaran seperti itu bisa dipahami bahwa: Al-Qur'an benar-benar nuzul pada hati-perasaankeyakinan dan pikiran mereka yang kemudian mendorong munculnya perbuatan baik ('amal shaleb) sehingga lebih lanjutmenghasilkan perubahan sosial, dari kehidupan yang tidak beradab menjadi beradab. Hidup yang semula senang berperang berubah menjadi senang ilmu dan perdamaian. Itulah salah satu pesan Al-Qur'an yang mestinya kita gali, pikirkan, kita olah-renungkan, kita yaqini dan lantas kemudian menjadi pemicu-pemacu amal kebaikan yang tanpa batas, yang tentu saja bisa dan dapat membantuk peradaban yang majumodern-global.

\section{PENUTUP}

Dari kelompok lima ayat pertama $\mathrm{Al}-$ Qur'an, bisa dipahami bahwa Al-Qur'an menetapkan nilai yang sangat tinggi bagi pencarian hikmah dan ilmu pengetahuan. Nabi Saw. yang adalah illiterate, sangat mencintai ilmu dan mendorong pengikutnya menuntut ilmu sebanyak-banyaknya, sampai pun ke negeri Cina. Sumber dari segalanya dalam Islam, baik yang doktrinal maupun yang praktikal adalah Al-Qur'an dan al-Sunnah, seperti dinyatakan Fazlur Rahman bahwa thedefinitive sources of Islamic doctrine and practice are two: the Qur'an and the Sunna.

Dari akar kata namanya, qara`a (membaca) dan kataba (menulis), menunjukkan bahwa Al-Qur'an atau al-Kitāb, dalam pengertian seluas-luasnya berkaitan kuat dengan pendidikan. Bahkan, tidak mungkin berbicara tentang pendidikan Islam bila tanpa mengambil Al-Qur'an sebagai rujukan. Sebab dalam pendidikan Islam, nilai-nilai Al-Qur'an merupakan elemen dasar dari kurikulum dan setiap lembaga pendidikan hendaknya konsen untuk membawa peserta didiknya kepada nilai yang selaras dengan Al-Qur'an.

Secara global, peradaban Islam nampaknya memang belum bisa atau belum cukup mampu membuat kehidupan manusia dan kemanusiaan bahagia dan menyenangkan sebagaimana dambaan pada umumnya manusia. Bahkan kehidupan manusia dan kemanusiaan (meski bisa jadi diluar kehendak 
dan kewenangan dunia pendidikan semata) mengalami hal-hal yang sebaliknya dari apa yang didambakan itu. eMengalami dan menyaksikan berbagai hal seperti itu, banyak manusia di banyak belahan bumi termasuk Indonesia menjadi terperangah-kebingungan, kemudian memberi respon secara sangat beragam, mulai dari yang wajar-rasional hingga respon ekstrem yang kemudian menimbulkan suasana tidak enak baru.

Dalam kaitannya dengan peradaban Islam, dengan universalitas dan semangat rabmatan lil'ạlamîn Islam itu sendiri, sesunguhnya secara normatif lebih dari cukup untuk menyatakan bahwa peradaban Islam, memiliki cakupan lebih luas dan lebih jauh dari itu semua. Persoalan sesunguhnya terletak pada "hanya tinggal" mengkonsepsikanmenteorisasikan-mengorganisasikan-nya dalam bentuk yang lebih kongkrit dan applicable.

Peradaban Islam mestinya, seperti dulu, mampu mendorong kebaikan dan kebangkitan peradaban umat manusia, hingga menjadi mercusuar peradaban dunia, dimana bekas dan pengaruhnya terus memancar hingga hari ini. Jangan dikira, paradaban modern dengan daya dorong ilmu pengetahuan dan teknologi modern itu tiba dengan sendirinya. Jangan dikira era global dan era digital sekarang ini datang dengan tiba-tiba. Semua itu bisa terjadi dan sampai ke kita adalah karena sebelumnya berkat jasa dan pengorbanan Kaum Muslimin di bidangnya masing-masing, terutama dalam bidang ilmu pengetahuan itu sendiri. Ini bukan basa-basi, tetapi adalah pengakuan dan pernyataan para ilmuan Barat dan Orientalis yang jujur, serta kenyataan historis yang tak dapat dipungkiri oleh siapapun.

Secara substansial, peradaban secara lebih spesifik pendidikan Islam dapat dimaknai sebagai yang melatih perasaan sedemikian rupa sehingga dalam sikap hidup, tindakan, keputusan dan pendekatan terhadap segala jenis pengetahuan, dipengaruhi nilai dan sadar akan nilai etis Islam.

Pendidikan Islam berkesinambungan sejalan dengan kontinuitas kehidupan manusia di bumi. Hal tersebut sekaligus menggambarkan bangunan pendidikan Islam, yang mencakup keseluruhan ruang lingkup nilai itu sendiri, yang dapat membentuk aspek-aspek kepribadian muslim. Kepribadian muslim terdiri dari perpaduan sinergis berbagai kerangka perkembangan, ada aspek fisik, psikis, rasio, sosial dan lain-lain dalam fase pertumbuhan yang beragam.

Selama ini, disiplin ilmu yang berbicara tentang hal-hal menyangkut sains dan teknlogi dan semacamnya, terkesan bahkan dipandang di luar kontek pendidikan apalagi pendidikan Islam. Padahal tidak seharusnya demikian, sebab pendidikan adalah pendidikan untuk manusia dan manusia terkait dengan semua hal yang melingkupinya. Apabila terakhir ini ada jargon "pendidikan untuk semua" yang dimaksudkan untuk semua manusia, kenapa tidak dibangun juga jargon "pendidikan semua" dengan maksud pendidikan yang mencakup semua hal yang dibutuhkan manusia. Itulah semangat dan sejatinya konten dari pendidikan Islam yang seharusnya "meliputi" keseluruhan kebutuhan manusia fisik-jasmaniah maupun psikis-ruhaniah, sehingga manusia bisa mendapatkan peningkatan kecerdasannya secara komplit. Dan Itulah semangat universalitas Islam sebagai rabmatan lil 'alamin.

Demikianlah sebaiknya, manusia terus berpendidikan, mendidik dirinya dan saling mendidik, terus belajar dan mengajar sekaligus beramal, agar mencapai tujuan penciptaanya sebagai manusia yang sempurna (insan kamil) sesamanya kira-kira yang juga terjadi dalam sikap keberagamaan. Ada yang menjalani dengan penghayatan dan pemahaman akan makna yang dikandungnya, ada pula yang tidak. Jadi, ketika kita berhenti belajar, sebuah 
kemandekan, stagnasi, kejumudan akan menutupi ruang pertumbuhan hidup kita.

\section{DAFTAR PUSTAKA}

al-Qattān, Manna‘ Khalīl. Studi Ilmu-Ilmu AlQurān. Jakarta: Pustaka Litera Antar Nusa, 1996.

Ashimi, Tijani Ahmad. 'Islamic Civilization: Factors Behind Its Glory and Decline'. International Journal of Bussiness, Economics and Law 9, no. 5 (2016): 180-84.

Dzulhadi, Qosim Nursheha. 'Islam Sebagai Agama Dan Peradaban'. Tsaqafah: Jurnal Peradaban Islam 11, no. 1 (2015): 151-68. https://doi.org/http://dx.doi.org/10.21 111/tsaqafah.v11i1.258.

Fawaid, Ah. 'Dinamika Kajian Al-Qur'an Di Barat Dan Dampaknya Pada Kajian AlQur'an Kontemporer'. Nuansa 10, no. 2 (2013): 229-58. https://doi.org/10.19105/nuansa.v10i2.1 70.

Khalil, Imad al-Din. Madkhal Ila Hadharah AlIslamiyyah. Lebanon: al-Markaz al-Tsaqafi al-'Arabi, 2005.

Lewis, Bernard. The Arab in Hostory. New York: Harper \& Row Publisher, 1967.

Luthfi, M. 'Membumikan Al-Qur'an: Peluang Dan Tantangan'. Al Qalam 20, no. 98 (2003): $21-40$.

Nasr, Seyyed Hossein. 'Al-Qur'an Dan Hadis Sebagai Sumber Dan Inspirasi Filsafat Islam'. In Ensiklopedi Filsafat Islam, edited by Sayyed Hossein Nasr and Oliver Leaman, 36. Bandung: Mizan, 2003.

Nasr, Seyyed Hossein, and Huston Smith. Islam: Religion, History and Civilization. Lahore: Suhail Academy, 2005.

Palmer, and Richard E. Hermenutics: Interpretation Theory in Schleurmacher, Dilthey, Heidegger, and Gadamer. Evanston: Northwestern University Press, 1969.

Poonwala, Ismail K. 'Al-Qur'ān Dalam Rasāil Ikhwān Al-Ṣ afā'. Ulumul Qur àn 9, no. 2 (1991): 39.

Pulungan, J. Suyuthi. Sejarah Peradaban Islam. Palembang: Grafindo Telindo Press, 2009.
Rahman, Fazlur. Islam. Chicago: The University of Chicago Press, 1979.

- Prophecy in Islam: Philosopby And Ortodoxy. London: George Allen \& Unwin LTD, 1938.

- 'The Qur'ānic Concept of God, the Universe and Man'. Islamic Studies 6, no. 1 (1967): 1-19. - Wabyu Ilabi Dan Nabi. Bandung: Mizan, 1989. 